\title{
Production, consumption and nutrient cycling in a laboratory mesocosm
}

\author{
M. R. Roman ${ }^{1}$, H. W. Ducklow ${ }^{1}$, J. A. Fuhrman ${ }^{2}$, C. Garside ${ }^{3}$, P. M. Glibert ${ }^{1}$, \\ T. C. Malone ${ }^{1}$, G. B. McManus ${ }^{2, *}$ \\ ${ }^{1}$ Horn Point Environmental Laboratories, University of Maryland, Center for Environmental and Estuarine Research, \\ Cambridge, Maryland 21613, USA \\ ${ }^{2}$ Marine Sciences Research Center, State University of New York, Stony Brook, New York 11794, USA \\ ${ }^{3}$ Bigelow Laboratory for Ocean Sciences, West Boothbay Harbor, Maine 04575, USA
}

\begin{abstract}
A mesocosm experiment was conducted in which estuarine plankton population dynamics and rates of production, consumption, and nitrogen uptake and release were compared for $13 \mathrm{~d}$ in $400 \mathrm{l}$ vats with and without additions of the diatom Thalassiosira weissflogii and the copepod Acartia tonsa. In the vats with copepods, both phytoplankton biomass and production were reduced by grazing whereas in the vats without copepods, nutrient limitation reduced both phytoplankton production and standing stock. Bacteria dominated both estimated heterotrophic carbon biomass and production early in the experiment. However toward the end of the experiment, the biomass of zooplankton was often greater than the combined carbon pools of phytoplankton, bacteria and heterotrophic flagellates. Highest release rates of ammonium and dissolved free amino acid nitrogen occurred in the vats with copepods. Highest bacterial growth rates also occurred in the presence of copepods suggesting that grazing activity and copepod excretion stimulated the growth of bacteria. An inverse relation between the biomass of copepods and flagellates suggests that the copepods consumed significant quantities of heterotrophic nanoflagellates. Estimated growth rates of flagellates were highest in the vats with copepods. Our results demonstrate that the presence of copepods can result in more efficient nutrient recycling, higher primary production/chlorophyll and greater production by bacteria and heterotrophic nanoflagellates.
\end{abstract}

\section{INTRODUCTION}

The importance of bacteria and microheterotrophs in aquatic environments has been emphasized in recent years. Much of the carbon flow and nutrient cycling in pelagic systems can occur through microbial food-webs (e. g. Williams 1981, Azam et al. 1983, Pace et al. 1984). The traditional concept of the macrozooplankton-dominated food web has been revised to include bacteria and protozoa. However, quantitative relationships between the macro- and micro-grazers as well as the conditions which distribute the biomass and production among different groups of organisms are unclear. For example, both theoretical (e. g. Williams 1981, Frost 1984, Fasham 1985) and field studies (e. g. Landry et al. 1984) have shown that the majority of primary production can flow through bacteria and protozoa. The 'mic-

\footnotetext{
- Present address: Institute of Ecosystem Studies, Box AB, Millbrook, New York 12545, USA
}

robial loop', which returns carbon 'lost' as dissolved organic carbon (DOC) to upper trophic levels, has been postulated as a means of increasing the efficiency of pelagic food-webs by maintaining energy in surface waters where it can be utilized by higher trophic levels. However, the transfer of material between the microbial food-web and macrozooplankton-fish trophic levels has not been well documented and there is some evidence that suggests that there is not significant exchange of material between the microbes and macrozooplankton. For example, an enclosed water column experiment (Ducklow et al. 1986) and a study in the Celtic Sea (Joint \& Williams 1985) both suggest that bacterioplankton are unlikely to be an important source of carbon for zooplankton in planktonic food webs.

As an attempt to increase our understanding of carbon flow and nutrient cycling in plankton communities, we initiated an interdisciplinary research project to study Microbial Exchanges and Couplings in Coastal 
Atlantic Systems (MECCAS). Prior to beginning our field research in the Chesapeake Bay Plume, we conducted a workshop to intercalibrate techniques, test assumptions, regarding experimental methods and attempt to partition the carbon flow in a plankton community. We constructed simple food webs using $400 \mathrm{l}$ vats by adding cultures of a diatom and a copepod to a naturally-occurring estuarine microbial community. The biomass, production and consumption of the various carbon pools and rates of nitrogen regeneration were followed for periods of 5 to $13 \mathrm{~d}$.

\section{METHODS}

Water from the Choptank River, a sub-estuary of the Chesapeake Bay, USA, (12 to $14 \mathrm{ppt}$ ), was filtered through $1 \mu \mathrm{m}$ nominal pore size cartridge filters (AMFCuno) into 4, indoor, 400 l fiberglass vats. Most of the bacteria and some of the protozoa and phytoplankton were able to pass the filters. The vats were conical, with the bottom ending in a drain. Airstones at the bottom of the vats provided sufficient circulation to keep particles in suspension. Fluorescent lights suspended over the vats produced light for $10 \mathrm{~h} \mathrm{~d}$. Water temperature in the vats ranged from 17 to $18^{\circ} \mathrm{C}$.

The experiment was initiated by adding nitrate to all the vats to attain a final concentration of $20 \mu \mathrm{M}$. Vats $P$ (phytoplankton) and PZ (phytoplankton + zooplankton) received an inoculum of the diatom Thalassiosira weissflogiu for an initial chlorophyll concentration of $4.3 \mu \mathrm{gl}^{-1}$. Initial concentrations of bacteria and heterotrophic nanoflagellates (HNAN) in the vats were $13 \times 10^{9}$ and $2 \times 10^{6} 1^{-1}$ respectively. We did not detect ciliates in any of the vats. Naupliar $\left(56 \mathrm{l}^{-1}\right)$, copepodite $\left(121^{-1}\right)$ and adult $\left(31^{-1}\right\}$ stages of the copepod Acartia tonsa were added to Vats PZ and Z (zooplankton) to give initial biomass concentrations of 63 and $42 \mu \mathrm{g} \mathrm{C} 1^{-1}$, respectively. A control (Vat C) tank received only the nitrate addition.

The vats were monitored for a variety of both standing stock and plankton rate measurements (Table 1 ). Rate and biomass measurements were conducted 2 to 4 times a day during the first part of the experiment (Days 1 to 3) and in the morning (ca $0900 \mathrm{~h}$ ) for the remainder of the experiment. Replicate samples (2 or 3) were taken for all rate measurements and biomass parameters. Rate measurements (Table 1) were conducted in front of a light bank which approximated the light intensity at the surface of the vats. Phytoplankton carbon was estimated by regressing chlorophyll concentration against the amount of particulate organic carbon during the period of increasing phytoplankton (Banse 1977). Combining all of the vat data, we found that $\mu \mathrm{g} \mathrm{CI^{-1 }}=48.2\left(\mu \mathrm{g}\right.$ chlorophyll $\left.\mathrm{l}^{-1}\right)+519.78(\mathrm{r}=$
0.77, $n=48$ ). Copepod carbon was estimated using a carbon conversion from dry weight measurements of preserved samples ( $\mathrm{C}=32 \%$ of dry weight; Roman et al. 1985). Carbon biomass of bacteria and HNAN were estimated from volume/carbon ratios (Table 1). With regard to the latter, a recent study (Borsheim \& Bratbak 1987) suggested that shrinkage during preservation may result in underestimates of HNAN biomass using the volume conversion of Fenchel \& Finlay (1983).

\section{RESULTS}

\section{Standing stocks and carbon biomass}

Chlorophyll concentrations were highest initially in the vats inoculated with Thalassiosira weissflogii ( $P$ and PZ: Fig. 1A). In PZ, chlorophyll concentrations were slightly lower than in $\mathrm{P}$ at the peak of the bloom, then decreased significantly after Day 4 when the copepod population increased. The bloom of $T$. weissflogii in $\mathrm{P}$ was sustained for a few more days than in $\mathrm{PZ}$, but crashed after Day 8 , and by the termination of the experiment there was less chlorophyll in $\mathrm{P}$ than in $\mathrm{PZ}$.

Table 1. Methods used for biomass and rate measurements

\begin{tabular}{|c|c|}
\hline Measurement & Technique \\
\hline Chlorophyll & $\begin{array}{l}\text { Fluorescence (Yentsch \& } \\
\text { Menzel 1963) }\end{array}$ \\
\hline Particulate carbon & $\begin{array}{l}\text { Perkin-Elmer elemental } \\
\text { analyzer }\end{array}$ \\
\hline Primary production & $\begin{array}{l}{ }^{14} \mathrm{C} \text {-bicarbonate (Steemann- } \\
\text { Nielsen } 1952 \text { ) }\end{array}$ \\
\hline Bacterial abundance & $\mathrm{AODC}^{1}$ (Hobbie et al. 1977) \\
\hline Bacterial biomass & $\begin{array}{l}\text { Cell conversion, } 20 \mathrm{fg} \mathrm{C} \\
\text { cell }^{-1} \text { (Bratback 1985) }\end{array}$ \\
\hline Bacterial production & $\begin{array}{l}{ }^{3} \text { H-thymidine (Fuhrman \& } \\
\text { Azam 1982) }\end{array}$ \\
\hline Flagellate abundance & $\begin{array}{l}\text { Epifluorescent microscopy } \\
\text { (Haas 1982) }\end{array}$ \\
\hline Flagellate biomass & $\begin{array}{l}\text { Volume conversion } 0.071 \mathrm{~g} \mathrm{C} \\
\mathrm{cm}^{-3} \text { (Fenchel \& Finlay 1983) }\end{array}$ \\
\hline Zooplankton abundance & Microscope counts \\
\hline Zooplankton biomass & $\begin{array}{l}\text { Dry weight-carbon conver- } \\
\text { sion (Roman et al. 1985) }\end{array}$ \\
\hline Zooplankton grazing & $\begin{array}{l}\text { Isotopic-labelling (Roman \& } \\
\text { Rublee 1981) }\end{array}$ \\
\hline $\mathrm{NH}_{4}$ & (Solorzano 1969) \\
\hline $\mathrm{NH}_{4}$ uptake and release & $\begin{array}{l}{ }^{15} \mathrm{~N} \text { isotope tracer and dilu- } \\
\text { tion (Glibert 1982) }\end{array}$ \\
\hline DFAN ${ }^{2}$ & $\begin{array}{l}\text { Reverse-phase HPLC }{ }^{3} \text { (Mop- } \\
\text { per \& Lindroth 1982) }\end{array}$ \\
\hline DFAN uptake and release ${ }^{4}$ & $\begin{array}{l}{ }^{3} \mathrm{H} \text {-amino acid isotope dilu- } \\
\text { tion (Fuhrman 1987) }\end{array}$ \\
\hline \multicolumn{2}{|c|}{$\begin{array}{l}{ }^{1} \text { AODC }=\text { acncine orange direct count } \\
{ }^{2} \text { DFAN = dissolved free amino acid nitrogen } \\
{ }^{3} \text { HPLC = high pressure liquid chromotography } \\
{ }^{4} \text { Concentrations and rate measurements apply only to } \\
\text { glutamic acid. serine, glycine and alanine }\end{array}$} \\
\hline
\end{tabular}


In Vats $\mathrm{Z}$ and $\mathrm{C}$, chlorophyll concentrations progressively increased over the first 8 to $10 \mathrm{~d}$ of the experiment due to the growth of small phytoflagellates and a small ( 3 to $4 \mu \mathrm{m}$ ) centric diatom (Fig. 1A). There was also a modest bloom $\left(4.7 \times 10^{3}\right.$ cells $\left.\mathrm{ml}^{-1}\right)$ of larger diatoms (including Chaetoceros spp.) by Day 6 in Vat C. Chlorophyll concentrations in $Z$ peaked before those in $C$, then decreased between Day 8 and 11 as the grazer biomass increased.

Bacterial abundance in all the vats was highest near the beginning of the experiment (Fig. 1B) with a secondary peak during Days 6 to 8. In general, there were more bacteria in the vats with copepods $(\mathrm{PZ}>\mathrm{P}$, $Z>C)$ than in the vats without them. In contrast to the bacteria, heterotrophic nanoflagellates (HNAN) abundance peaked on Day 3 of the experiment, which may have caused the decrease in bacteria (Fig. 1C). The highest concentration of HNAN occurred in the vats without copepods ( $P>P Z, C>Z$ ) suggesting that copepods were grazing the HNAN.

Zooplankton biomass (Fig. 2) in the vats increased by almost an order of magnitude over the $13 \mathrm{~d}$ experiment. Zooplankton increased at a greater rate in $\mathrm{PZ}$ (with Thalassiosira weissflogi) as compared to $Z$ (without $T$. weissflogi). There was a 3 -fold increase in naupliar biomass in PZ between Days 3 and 4 which resulted in peak concentrations of adults between Days 8 and 11 . The biomass of copepodites in both vats remained fairly constant. The major increase in naupliar biomass in Z occurred between Days 8 and 11 so that zooplankton biomass would have likely increased in this vat with their development to copepodites and adults.

Comparing the estimated carbon biomass of the various plankton components in PZ and Z (Fig. 3) we see that early in the experiment the biomass of heterotrophs was dominated by bacteria. However by Day 5 , the biomass of copepods was equal to, or greater than the biomass of bacteria. The ratio of bacteria/phytoplankton (Table 2) was usually higher in the presence of copepods in the vats with the diatom inoculum $(\mathrm{PZ}>\mathrm{P})$. In contrast, the biomass of flagellates relative to their bacterial prey was less in the vats with copepods ( $\mathrm{P}>\mathrm{PZ} ; \mathrm{C}>\mathrm{Z}$ ).

\section{Production rates}

Similar to chlorophyll, primary production rates peaked early in the experiment in $\mathrm{P}$ and $\mathrm{PZ}$ and later in the experiment in $\mathrm{Z}$ and $\mathrm{C}$ (Fig. $4 \mathrm{~A}$ ). The presence of copepods appeared to stimulate phytoplankton production, as peak production levels occurred earlier in the vats with copepods.

Peaks in bacterial thymidine incorporation in $\mathrm{P}$ and $\mathrm{PZ}$ lagged the maxima in phytoplankton production by several days (Fig. 4B). In contrast, thymidine incorporation rates in $Z$ were highest initially, then decreased, with a secondary peak occurring coincidently with the peak in phytoplankton production (Day 8). In $\mathrm{C}$, thy-
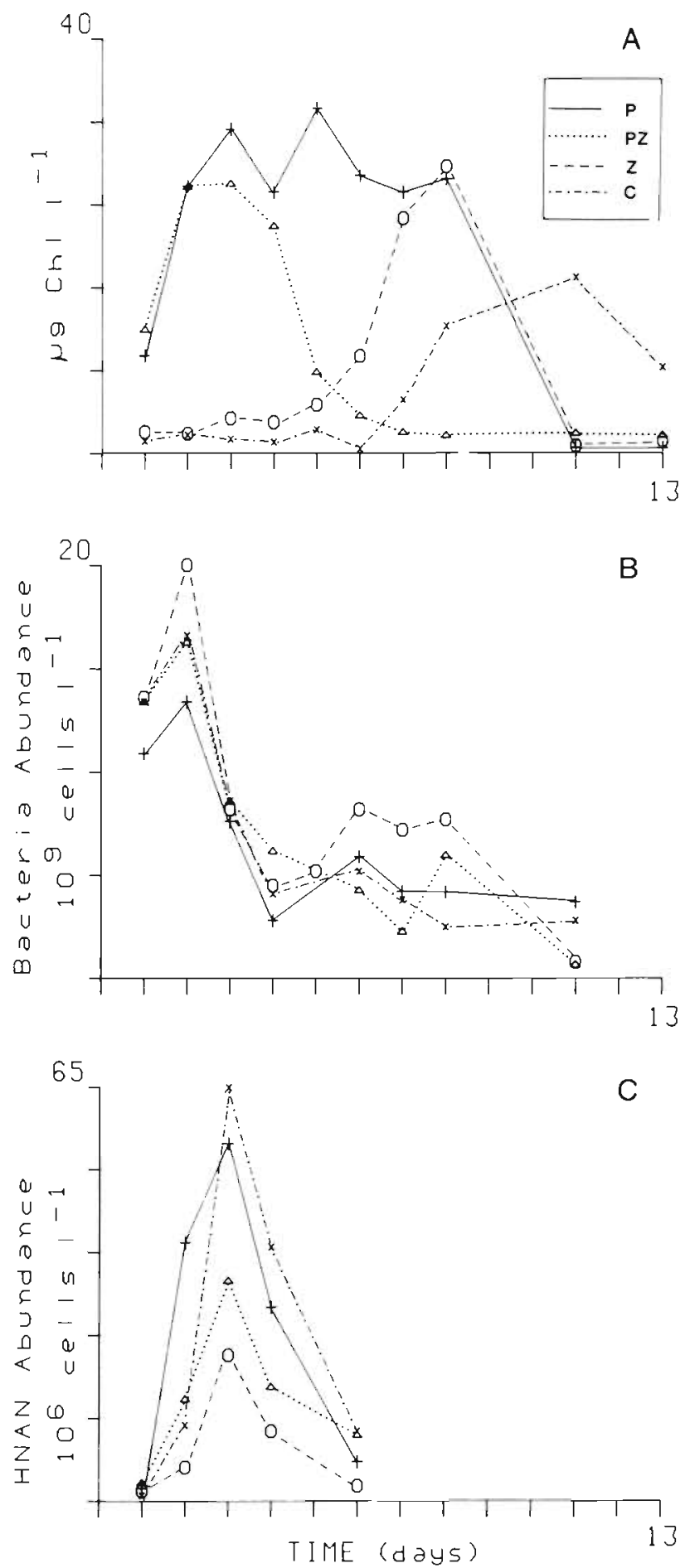

Fig. 1. (A) Chlorophyll a $\left(\mu \mathrm{g} \mathrm{l}^{-1}\right)$; (B) bacteria abundance $\left(10^{9}\right.$ cell $\left.1^{-1}\right)$; and $(C)$ HNAN abundance $\left(10^{6}\right.$ cells $\left.1^{-1}\right)$ in Vats $P(+)$, $\mathrm{PZ}(\Delta), \mathrm{Z}(0)$ and $\mathrm{C}(\mathrm{X})$ 
NAUPLII

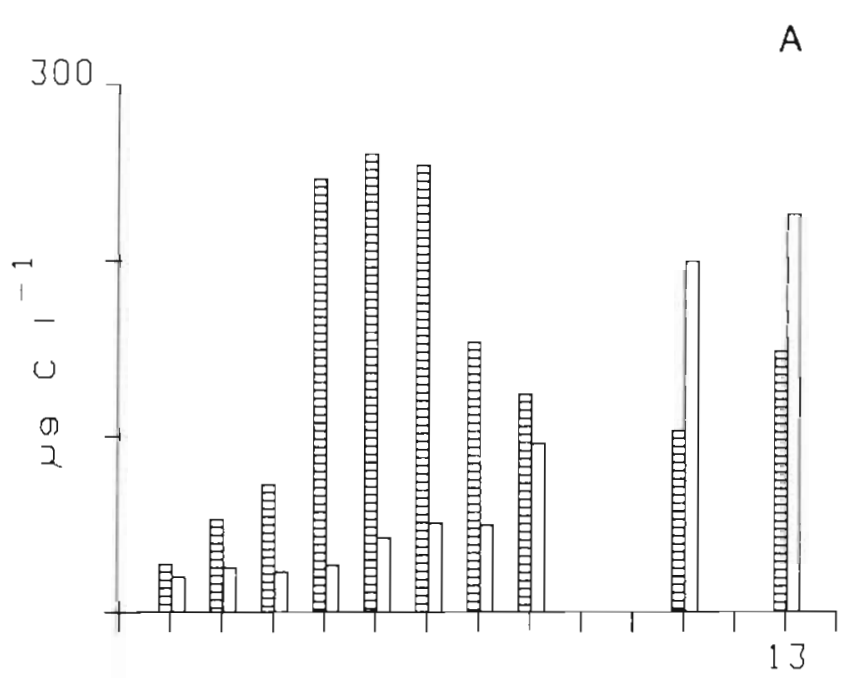

ADULTS

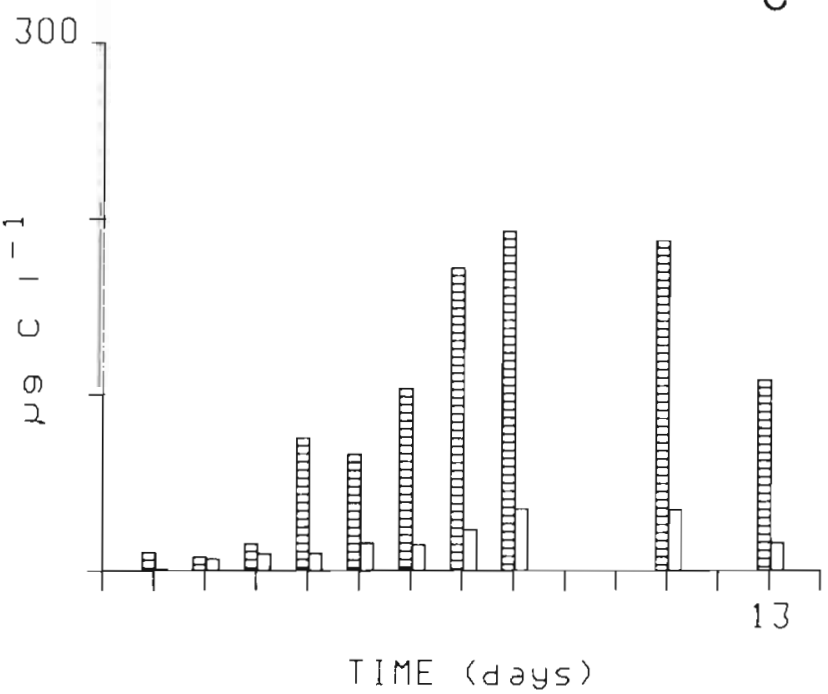

COPEPODITES

B

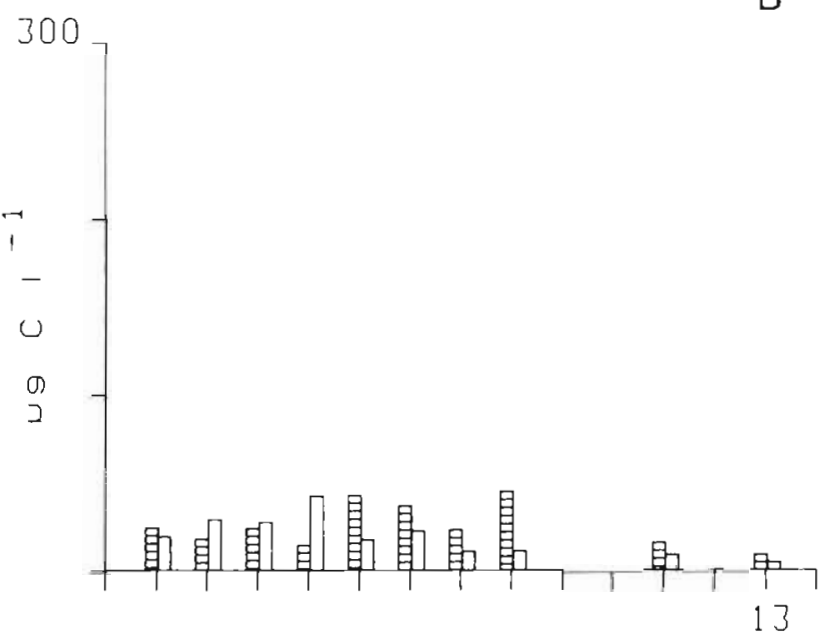

TOTAL

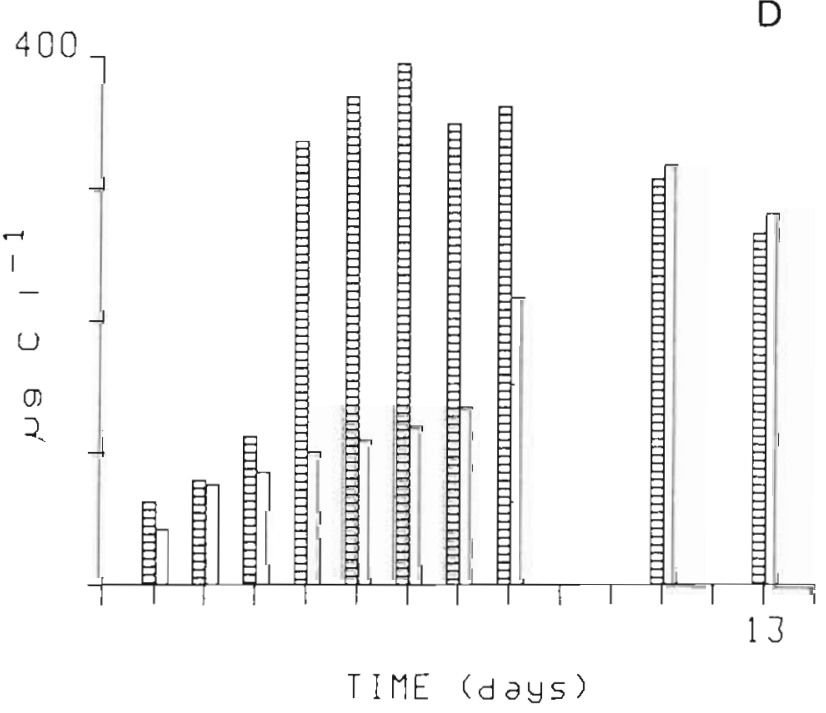

Fig. 2. Acartia tonsa. Biomass ( $\mu \mathrm{C} \mathrm{Cl}^{-1}$ ) of (A) nauplii; (B) copepodites, (C) adults, and (D) total stages in Vats PZ (shaded) and Z (open)

midine incorporation decreased from a high initial value to low, uniform levels for the remainder of the experiment. Over most of the experiment, thymidine incorporation in the vats with copepods was higher than the vats without them $(\mathrm{PZ}>\mathrm{P}, \mathrm{Z}>\mathrm{C}$ ).

Daily production rates of phytoplankton were extrapolated from morning (0900 h) incubations (2h, Fig. 5). On 2 of the $7 \mathrm{~d}$ phytoplankton production was measured, both morning (ca $0900 \mathrm{~h}$ ) and afternoon (ca $1400 \mathrm{~h}$ ) incubations were conducted. Using a paired sample t-test, we found no significant ( $p>0.05, n=8$ ) differences between morning and aftemoon primary production estimates. Over the entire experiment the amount of primary production appeared to be a function of phytoplankton biomass ( $\mu \mathrm{g} \mathrm{C} \mathrm{l}^{-1} \mathrm{~h}^{-1}=0.87(\mu \mathrm{g}$ chlorophyll $\left.\mathrm{l}^{-1}\right)+87.66(\mathrm{r}=0.87, \mathrm{n}=36)$. Bacterial carbon production was estimated by converting thymidine incorporation rates $\left(0.04 \mu \mathrm{g} C\right.$ pmol $\left.\mathrm{TdR}^{-1}\right)$ and extrapolating morning incubations to daily production rates (Fig. 5). The relationship of $2 \times 10^{18}$ cells produced per mole of $\left[{ }^{3} \mathrm{H}\right]$ thymidine incorporated (Fuhrman \& Azam 1982) was verified experimentally, as described by Ducklow \& Hill (1985). Cell densities were converted to carbon biomass from cell measurements $\left(0.1 \mu^{3}\right.$ cell $\left.^{-1}\right)$ and a carbon cell ${ }^{-1}$ conversion (Bratback 1985). On 4 of the $10 \mathrm{~d}$ bacterial production 
was measured, both morning (ca $0900 \mathrm{~h}$ ) and afternoon (ca $1400 \mathrm{~h}$ ) incubations were conducted. Using a paired sample t-test, we found no significant $(\mathrm{p}>0.05, \mathrm{n}=16)$ differences between morning and afternoon bacterial production estimates. Thus for both phytoplankton and bacteria we feel that extrapolation of the morning incubation gives a reasonable estimate of daily production rates.

Calculation of the production of heterotrophic nanoflagellates is difficult because of infrequent sampling and because of probable predation by copepods on HNAN in Vats PZ and Z. Production rates based on the increase in carbon biomass of HNAN over the first $3 \mathrm{~d}$ of the experiment ranged from 8 to $77(\overline{\mathrm{x}}=37, \mathrm{n}=7) \mu \mathrm{g}$ $\mathrm{C}^{-1} \mathrm{~d}^{-1}$. A more extensive data set can be attained by assuming that: (1) HNAN are the sole source of bacterial mortality (there were no ciliates in the vats); (2) bacterial mortality $=$ production $^{\mathrm{D} 1}+$ biomass $^{\mathrm{D} 1}-$ biomass $^{\mathrm{D} 2}$ (D1 = Day N, D2 = Day N + 1); (3) the gross growth efficiency of HNAN is $38 \%$ (Fenchel 1982). An independent check on HNAN gross growth efficiency can be made using the increases in HNAN biomass during the first $3 \mathrm{~d}$ of the experiment and estimates of HNAN ingestion based on assumed clearance rates (Fenchel 1982). Using these estimates we found that HNAN gross growth efficiencies ranged from 11 to

Table 2. Ratios of the standing stocks of phytoplankton, bacteria, flagellates and zooplankton. Heterotrophic carbon is the sum of bacteria, flagellates and zooplankton

\begin{tabular}{|c|c|c|c|c|c|c|c|c|c|}
\hline \multirow[b]{2}{*}{ Vat } & \multicolumn{9}{|c|}{ Day } \\
\hline & 1 & 2 & 3 & 4 & 5 & 6 & 7 & 8 & 11 \\
\hline \multicolumn{10}{|c|}{ Bacteria/phytoplankton } \\
\hline $\mathrm{P}$ & 0.48 & 0.22 & 0.10 & 0.04 & - & 0.10 & 0.08 & 0.06 & 3,08 \\
\hline $\mathrm{PZ}$ & 0.46 & 0.26 & 0.14 & 0.12 & - & 0.48 & 0.46 & 1.40 & 0.14 \\
\hline $\mathrm{Z}$ & 2.68 & 4.54 & 1.00 & 0.62 & 0.46 & 0.36 & 0.14 & 0.12 & 0.48 \\
\hline C & 4.62 & 3.86 & 2.56 & 1.54 & - & 0.48 & 0.30 & 0.08 & 0.06 \\
\hline \multicolumn{10}{|c|}{ Bacteria/heterotrophs } \\
\hline $\mathrm{P}$ & 0.98 & 0.77 & 0.67 & 0.62 & - & 0.84 & - & - & - \\
\hline $\mathrm{PZ}$ & 0.79 & 0.72 & 0.49 & 0.25 & - & 0.17 & - & - & - \\
\hline $\mathrm{Z}$ & 0.86 & 0.83 & 0.56 & 0.43 & - & 0.57 & - & - & - \\
\hline $\mathrm{C}$ & 0.09 & 0.90 & 0.67 & 0.66 & - & 0.83 & - & - & - \\
\hline \multicolumn{10}{|c|}{ Flagellates/bacteria } \\
\hline $\mathrm{P}$ & 0.02 & 0.30 & 0.50 & 0.60 & - & 0.18 & - & - & - \\
\hline $\mathrm{PZ}$ & 0.02 & 0.14 & 0.38 & 0.26 & - & 0.32 & - & - & - \\
\hline $\mathrm{Z}$ & 0.01 & 0.02 & 0.28 & 0.20 & - & 0.03 & - & - & - \\
\hline \multirow[t]{2}{*}{$\mathrm{C}$} & 0.01 & 0.11 & 0.49 & 0.51 & - & 0.20 & - & - & - \\
\hline & & & & & & & - & - & - \\
\hline \multicolumn{10}{|c|}{ Flagellates/heterotrophs } \\
\hline $\mathrm{P}$ & 0.02 & 0.23 & 0.33 & 0.38 & - & 0.16 & - & - & - \\
\hline $\mathrm{PZ}$ & 0.02 & 0.10 & 0.19 & 0.07 & - & 0.05 & - & - & - \\
\hline Z & 0.01 & 0.02 & 0.16 & 0.09 & - & 0.02 & - & - & - \\
\hline \multirow[t]{2}{*}{$\mathrm{C}$} & 0.01 & 0.10 & 0.33 & 0.34 & - & 0.04 & - & - & - \\
\hline & & & & & & & - & - & - \\
\hline \multicolumn{10}{|c|}{ Zooplankton/phytoplankton } \\
\hline $\mathrm{PZ}$ & 0.11 & 0.06 & 0.07 & 0.32 & 0.97 & 2.21 & 3.46 & 4.20 & 3.20 \\
\hline Z & 0.42 & 0.83 & 0.50 & 0.69 & 0.49 & 0.27 & 0.12 & 0.16 & 9.32 \\
\hline \multicolumn{10}{|c|}{ Zooplankton/flagellates } \\
\hline $\mathrm{PZ}$ & 9.00 & 1.76 & 1.72 & 10.18 & - & 14.59 & - & - & - \\
\hline$z$ & 6.00 & 6.91 & 1.74 & 5.56 & - & 24.00 & - & - & - \\
\hline \multicolumn{10}{|c|}{ Zooplankton/heterotrophs } \\
\hline $\mathrm{PZ}$ & 0.19 & 0.18 & 0.32 & 0.68 & - & 0.78 & - & - & - \\
\hline$z$ & 0.13 & 0.15 & 0.28 & 0.48 & - & 0.42 & - & - & - \\
\hline \multicolumn{10}{|c|}{ Heterotrophs/phytoplankton } \\
\hline $\mathrm{P}$ & 0.50 & 0.28 & 0.14 & 0.07 & - & 0.11 & - & - & - \\
\hline PZ & 0.59 & 0.36 & 0.33 & 0.47 & - & 2.85 & - & - & - \\
\hline Z & 3.14 & 5.50 & 1.79 & 1.44 & - & 0.64 & - & - & - \\
\hline $\mathrm{C}$ & 4.66 & 4.28 & 3.82 & 2.34 & - & 0.58 & - & - & - \\
\hline
\end{tabular}



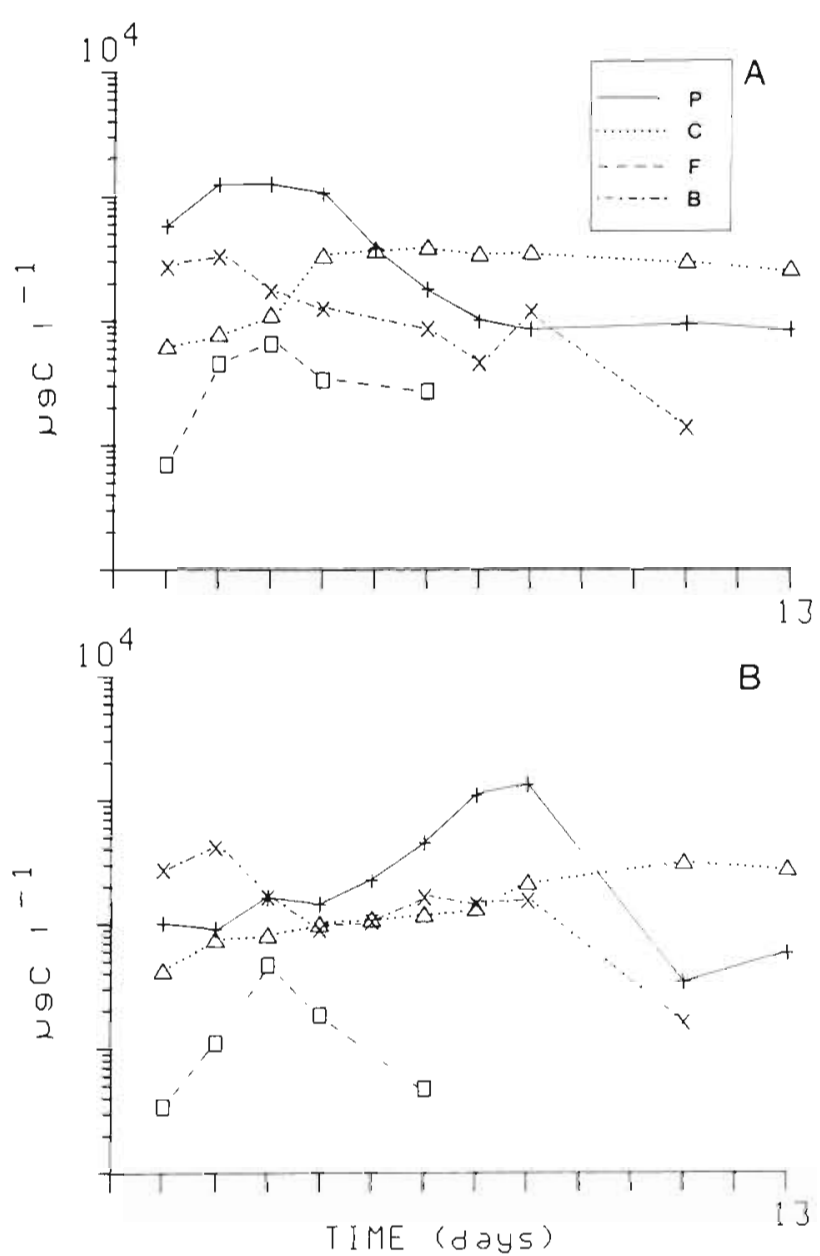

Fig. 3. Carbon biomass $\left(\log _{10} \mu \mathrm{g} \mathrm{Cl}^{-1}\right)$ of phytoplankton $(+)$, bacteria $(X)$, flagellates $(\square)$ and copepods $(\Delta)$ in $(A)$ Vat PZ and (B) Vat Z

$50 \%(\overline{\mathrm{x}}=32 \%, \mathrm{n}=7)$. The production estimates based on the aforementioned assumptions (Fig. 5) are in the same range as those calculated from increases in biomass but tend to be higher because the calculation assumes no HNAN mortality. Using these estimates as relative indices of HNAN production, we find that in general HNAN production follows a pattern similar to that of bacterial production and that HNAN production is usually highest in the vats with copepods $(\mathrm{PZ}>\mathrm{P}$, $\mathrm{Z}>\mathrm{C}$ ).

Zooplankton production, calculated from the daily increase in biomass, was higher in PZ than $Z$ except at the end of the experiment (Fig. 5). Peak daily zooplankton production occurred on Day $3\left(224 \mu \mathrm{g} \mathrm{C} 1^{-1} \mathrm{~d}^{-1}\right)$ in PZ and on Day $7\left(83 \mu \mathrm{g} \mathrm{Cl}^{-1} \mathrm{~d}^{-1}\right)$ in $\mathrm{Z}$. A similar pattern of production is found if we assume a $20 \%$ gross growth efficiency for the copepods (Tranter 1974) and
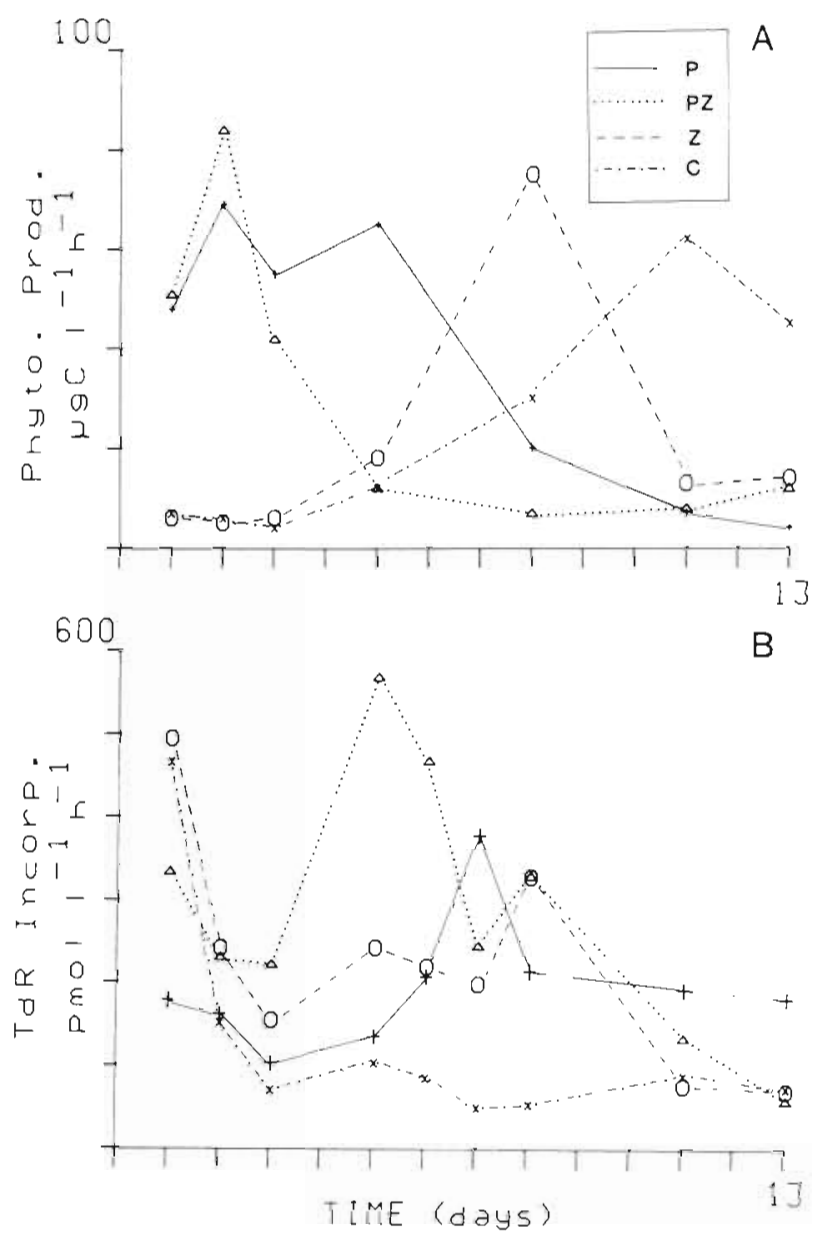

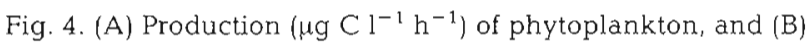
thymidine incorporation by bacteria $\left(\mathrm{pmol}^{-1} \mathrm{~h}^{-1}\right)$. Symbols as in Fig. 1

estimate that zooplankton are the sole source of phytoplankton mortality (ingestion $=$ phytoplankton production $^{\mathrm{D} 1}+$ biomass $^{\mathrm{D} 1}-$ biomass $^{\mathrm{D} 2}$ )

Comparing the estimated production rates of the various plankton groups (Fig. 5) we find that in $\mathrm{PZ}$, as phytoplankton production decreased bacterial production increased. In $Z$, estimated carbon production by bacteria was greater than carbon production by phytoplankton until Day 6 , with a secondary peak in bacteria coinciding with the maximum in primary production (Day 8). Compared to the other trophic groups, copepod carbon production was the lowest except at peak production values (Day 3 in PZ, Days 7, 8 in Z). The production/biomass ratio of the groups (Table 3 ) reflects that turnover was inversely related to size, as $\mathrm{P} / \mathrm{B}$ of bacteria $>$ flagellates $>$ phytoplankton $>$ zooplankton. High P/B ratios for HNAN on Days 1 and 6 

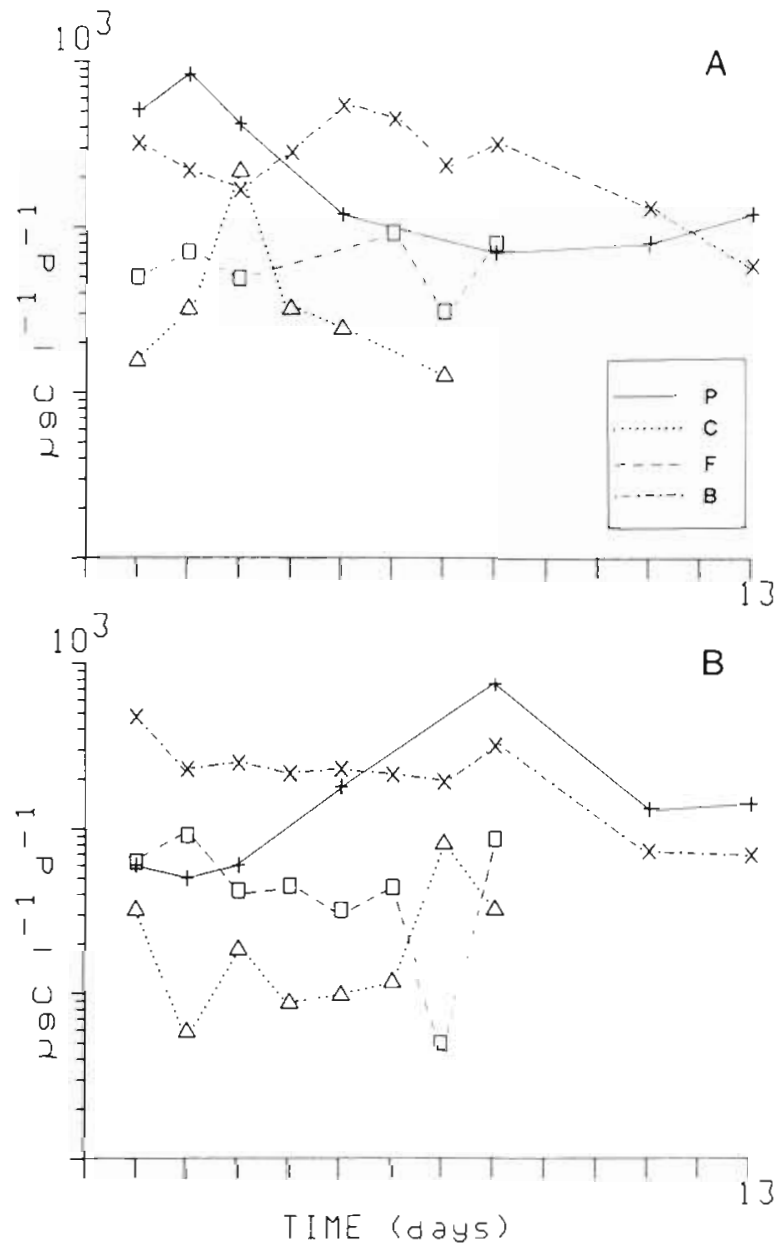

Fig. 5. Production $\left(\log _{10} \mu \mathrm{g} C \mathrm{C}^{-1} \mathrm{~d}^{-1}\right)$ of phytoplankton, bacteria, flagellates and copepods in (A) Vat PZ and (B) Vat Z. Symbols as in Fig. 3 may be the result of overestimates of production rates. In general, the turnover rates of bacteria and HNAN were highest in the vats with copepods $(\mathrm{PZ}>\mathrm{P}$, $\mathrm{Z}>\mathrm{C}$ ).

\section{Nitrogen fluxes}

The dissolved pools, uptake rates and regeneration rates of both $\mathrm{NH}_{4}^{+}$(Fig. 6) and dissolved free acid amino nitrogen (DFAN) (Fig. 7) were usually highest in the vats which contained copepods ( $\mathrm{PZ}>\mathrm{P}, \mathrm{Z}>\mathrm{C}$ ). The $\mathrm{NH}_{4}^{+}$uptake rates on Day 1 exceeded those measured on subsequent days by several-fold; this corresponded, especially for $\mathrm{P}$ and $\mathrm{PZ}$, to the period of rapid increase in phytoplankton biomass. Regeneration rates were not adequate to supply the entire nitrogen demand, thus we observed a rapid decrease in both ambient $\mathrm{NO}_{3}^{-}$and $\mathrm{NH}_{4}^{+}$in these vats from Day 1 to Day $2\left(\mathrm{NO}_{3}^{-}\right.$concentration and uptake data not reported; Fig. 6). During Days 2 and 3 the uptake and regeneration rates in $P Z$ exceeded the rates in $\mathrm{P}$ in spite of the fact that phytoplankton biomass during this period was greater in $P$. Thus, turnover rates of nitrogen were higher in $\mathrm{PZ}$ than $\mathrm{P}$ over these 2 days. In the vats without added phytoplankton, $\mathrm{NH}_{4}^{+}$uptake and regeneration rates were initially higher in the vat without added copepods $\left(\mathrm{C}>\mathrm{Z}\right.$ ). However by Day 5 (the last day $\mathrm{NH}_{4}^{+}$fluxes were measured) uptake rates in $P$ and $Z$ exceeded the rates in $\mathrm{PZ}$ and $\mathrm{C}$ respectively, and regeneration rates were highest in the vats with copepods $(P Z>P$, $Z>C$ ). This corresponds to the period when phyiuplankton in PZ began to decrease following the

Table 3. Production/biomass ratios $\left(\mu \mathrm{g} \mathrm{Cl}^{-1} \mathrm{~d}^{-1} / \mu \mathrm{g} \mathrm{Cl} \mathrm{l}^{-1}\right)$ of phytoplankton, bacteria, flagellates and zooplankton

\begin{tabular}{|c|c|c|c|c|c|c|c|c|c|c|}
\hline \multirow[b]{2}{*}{ Vat } & \multicolumn{10}{|c|}{ Day } \\
\hline & 1 & 2 & 3 & 4 & 5 & 6 & 7 & 8 & 11 & 13 \\
\hline \multicolumn{11}{|c|}{ Phytoplankton } \\
\hline $\mathrm{P}$ & 1.08 & 0.56 & 0.33 & - & 0.41 & - & - & 0.16 & 3.75 & 1.67 \\
\hline $\mathrm{PZ}$ & 0.88 & 0.68 & 0.34 & - & 0.32 & - & - & 0.81 & 0.83 & 1.39 \\
\hline Z & 0.59 & 0.55 & 0.37 & - & 0.80 & - & - & 0.56 & 3.82 & 2.41 \\
\hline $\mathrm{C}$ & 1.21 & 0.70 & 0.60 & - & 1.09 & - & - & 0.51 & 0.76 & 1.13 \\
\hline \multicolumn{11}{|c|}{ Bacteria } \\
\hline $\mathrm{P}$ & 0.79 & 1.74 & 1.58 & 2.50 & 1.48 & 1.66 & 4.33 & 2.45 & 2.46 & - \\
\hline $\mathrm{PZ}$ & 1.20 & 0.68 & 1.23 & 1.35 & 5.26 & 5.26 & 5.13 & 2.63 & 14.00 & - \\
\hline z & 1.75 & 0.56 & 0.90 & 2.78 & 2.21 & 1.29 & 1.33 & 2.05 & 4.50 & - \\
\hline $\mathrm{C}$ & 1.66 & 0.43 & 0.40 & 0.88 & 1.09 & 0.79 & 0.63 & 1.04 & 1.54 & - \\
\hline \multicolumn{11}{|c|}{ Flagellates } \\
\hline $\mathrm{p}$ & 5.75 & 0.63 & 0.47 & - & - & 2.00 & - & - & - & - \\
\hline $\mathrm{PZ}$ & 7.14 & 1.58 & 0.75 & - & - & 3.44 & - & - & - & - \\
\hline $\mathrm{Z}$ & 21.00 & 8.27 & 0.89 & 2.50 & - & 8.80 & - & - & - & - \\
\hline$C$ & 36.00 & 1.61 & 0.36 & - & - & 1.06 & - & - & - & - \\
\hline \multicolumn{11}{|c|}{ Zooplankton } \\
\hline PZ & 0.26 & 0.42 & 2.00 & 0.10 & 0.06 & 0 & 0.04 & 0 & 0 & - \\
\hline Z & 0.79 & 0.08 & 0.23 & 0.09 & 0.09 & 0.14 & 0.62 & 0.15 & 0 & - \\
\hline
\end{tabular}



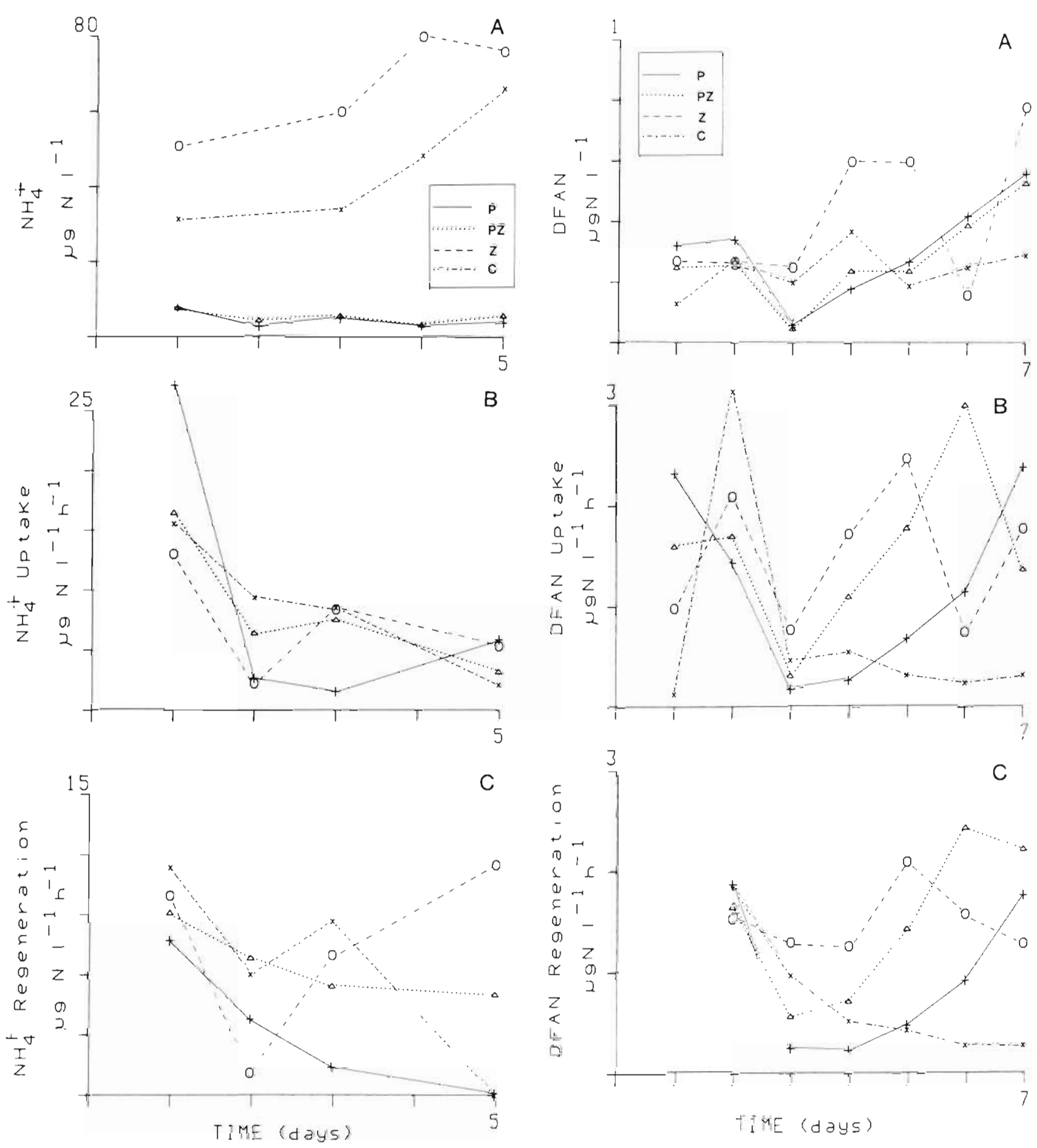

Fig. 6. Ammonium. (A) Standing stock ( $\mu \mathrm{g}^{\mathrm{N} \mathrm{l}^{-1}}$ ); (B) uptake ( $\left.\mu \mathrm{g} \mathrm{NH} \mathrm{NH}_{4} \mathrm{l}^{-1} \mathrm{~h}^{-1}\right) ;(\mathrm{C})$ regeneration $\left(\mu \mathrm{g} \mathrm{N} l^{-1} \mathrm{~h}^{-1}\right)$. Symbols as in Fig. 1

Fig. 7. Dissolved free amino acid nitrogen (DFAN). (A) standing stock $\left(\mu \mathrm{g} \mathrm{N} 1^{-1}\right)$; (B) uptake $\left(\mu \mathrm{g} \mathrm{NI}^{-1} \mathrm{~h}^{-1}\right)$; (C) regeneration (ug $\mathrm{N}^{-1} \mathrm{~h}^{-1}$ ). Symbols as in Fig. 1

increase in copepod biomass. For $Z$, this was the period during which phytoplankton production began to increase. However, there were considerable fluctuations in $\mathrm{NH}_{4}^{+}$uptake and regeneration over each day

(afternoon data not reported), thus precluding the construction of daily mass balances in terms of nitrogen.

Concentrations of DFAN (Fig. 7) did not change appreciably over the first $7 \mathrm{~d}$ of sampling (after which 
DFAN was not measured). After Day 2, the release rates of DFAN (Fig. 7) in the vats with copepods were at least twice the rates determined in the vats without copepods ( $\mathrm{PZ}>\mathrm{P}, \mathrm{Z}>\mathrm{C}$ ). This period corresponded with the peak in zooplankton biomass in $\mathrm{PZ}$ and preceeded the peak copepod biomass in $Z$. This release of DFAN resulted in greater uptake rates of DFAN (Fig. 7) which likely stimulated the higher bacterial production rates in the copepod vats (Fig. 4).

\section{Consumption rates}

Bacterial carbon demand can be estimated by assuming a $50 \%$ gross growth efficiency (Billen et al. 1980, Azam et al. 1983, Williams 1984, Findlay et al. 1986; but see Bjornsen 1986 for gross growth efficiencies around $20 \%$ ) and calculating carbon utilization by doubling the production values (Table 4). Because bacterial production rates were generally higher in the vats with copepods ( $\mathrm{PZ}>\mathrm{P}, \mathrm{Z}>\mathrm{C}$ ), estimated carbon uptake by the bacteria was also greater. During the latter part of the experiment in $\mathrm{P}$ and $\mathrm{PZ}$ and early in $\mathrm{Z}$ and $C$ when primary production was relatively low, the estimated bacterial carbon demand exceeded daily primary production. Dissolved organic carbon release from phytoplankton produced previously, carbon release by HNAN and copepods (DOC and in fecal pellets), and dissolved organic carbon in the seawater used to fill the vats could have also contributed to carbon uptake by bacteria.
Carbon consumption by heterotrophic nanoflagellates can be estimated from biomass by assuming a clearance rate of $8 \times 10^{4}$ body volumes $h^{-1}$. This is the average for the flagellates studied in culture by Fenchel (1982), omitting the value for Actinomonas mirabilis, an organism adapted to feed on large bacteria (see Fenchel 1984). These clearance rates multiplied by bacterial standing stocks yield grazing rates $\left(=\mu \mathrm{g} \mathrm{Cl}^{-1} \mathrm{~d}^{-1}\right)$ of 24 to $586, \overline{\mathrm{x}}=210(\mathrm{P}) ; 50$ to $398, \overline{\mathrm{x}}=$ 184 (PZ); 22 to $208, \bar{x}=84(\mathrm{Z}) ; 16$ to $390, \bar{x}=176$ (C). These daily bacterial removal estimates range from 6 to $277 \%(\bar{x}=90 \%)$ of bacterial standing stocks and 4 to $568 \%(\overline{\mathrm{x}}=99 \%)$ of daily bacterial production. The consumption of bacteria can also be estimated by comparing changes in their production and biomass (Table 5). These estimates reflect the total loss of bacteria by cell death and lysis, HNAN grazing and copepod grazing. Because they include other losses (cell death and copepod grazing) mass balance estimates of bacterial loss are higher than the estimates based on published HNAN clearance rates. Contrary to the pattern of HNAN grazing based on published clearance rates, the highest loss of bacteria appeared to occur in the tanks with copepods. As copepods have been shown to be relatively inefficient in filtering bacteria (Roman 1984), bacterial loss may have occurred as a result of HNAN grazing

The potential carbon demand by copepods can be estimated from their daily production rates using a $20 \%$ gross growth efficiency (Tranter 1976; Table 4). These ingestion range from 65 to $1120 \mu \mathrm{g} \mathrm{C} \mathrm{l}^{-1} \mathrm{~d}^{-1}$ in

Table 4. Estimated carbon demand ( $\mu \mathrm{g} \mathrm{Cl}^{-1} \mathrm{~d}^{-1}$ ) of bacteria and zooplankton calculated from daily production rates and gross growth efficiencies of $50 \%$ (bacteria) and 20\% (copepods). Carbon demand also expressed as a fraction of daily primary production

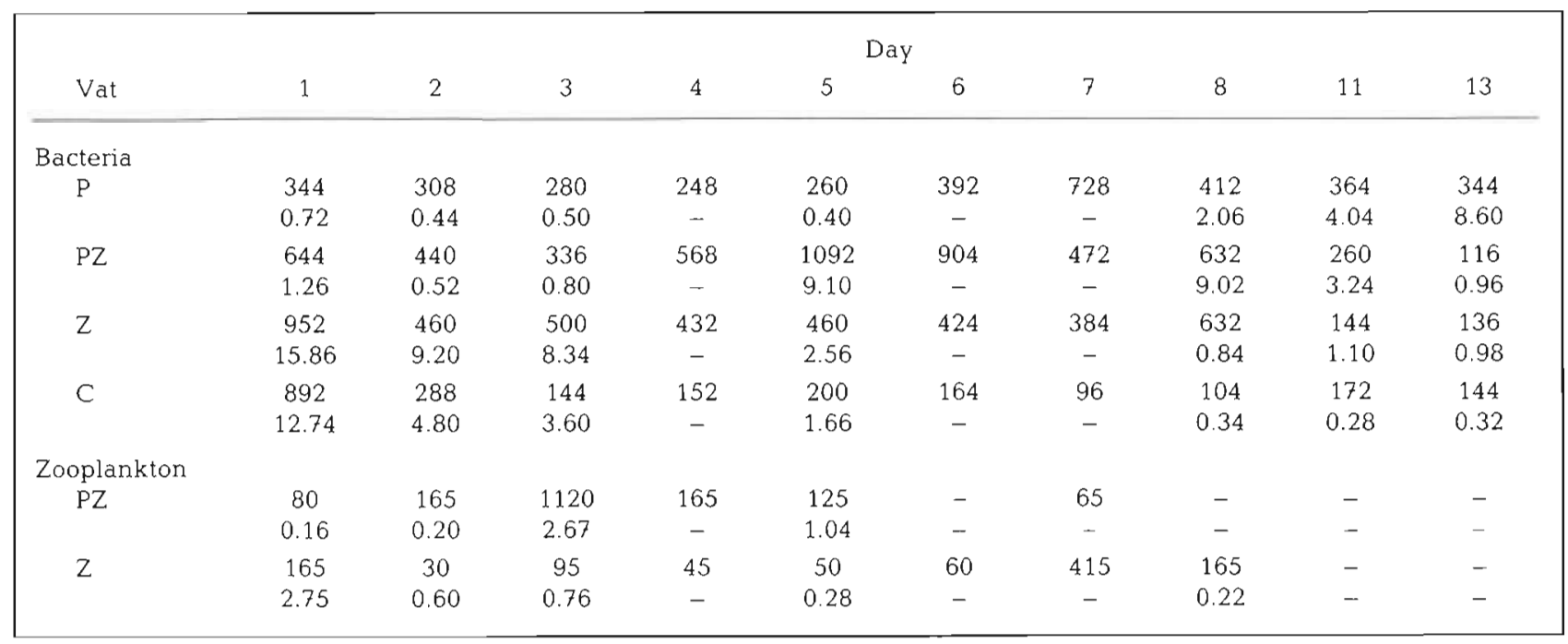


Table 5. Estimated consumption ( $\mu \mathrm{C} \mathrm{Cl}^{-1} \mathrm{~d}^{-1}$ ) of phytoplankton, bacteria and flagellates, calculated as: production ${ }^{\mathrm{D} 1}+$ biomass $^{\mathrm{D} 1}$ - biomass ${ }^{D 2}$ Daily production averaged for Days 8,11 and 11, 13

\begin{tabular}{|c|c|c|c|c|c|c|c|c|c|}
\hline \multirow[b]{2}{*}{ Vat } & \multicolumn{9}{|c|}{ Day } \\
\hline & 1 & 2 & 3 & 4 & 5 & 6 & 7 & 8 & 11 \\
\hline \multicolumn{10}{|c|}{ Phytoplankton } \\
\hline $\mathrm{P}$ & -312 & 282 & 986 & - & 962 & - & - & 561 & 65 \\
\hline $\mathrm{PZ}$ & -152 & 825 & 617 & - & 321 & - & - & 72 & 105 \\
\hline Z & 70 & -22 & 79 & - & -45 & - & - & 872 & 123 \\
\hline $\mathrm{C}$ & 42 & 79 & 54 & - & 14 & - & - & 385 & 744 \\
\hline \multicolumn{10}{|c|}{ Bacteria } \\
\hline $\mathrm{P}$ & 122 & 270 & 192 & 108 & 100 & 230 & 364 & 198 & - \\
\hline $\mathrm{PZ}$ & 264 & 374 & 260 & 188 & 566 & 492 & 162 & 292 & - \\
\hline Z & 334 & 480 & 222 & 236 & 170 & 232 & 182 & 240 & - \\
\hline $\mathrm{C}$ & 382 & 304 & 158 & 62 & 88 & 110 & 74 & 68 & - \\
\hline \multicolumn{10}{|c|}{ Flagellates } \\
\hline $\mathrm{P}$ & -54 & -127 & 78 & - & - & - & - & - & - \\
\hline $\mathrm{PZ}$ & 12 & 51 & 81 & - & - & - & - & - & - \\
\hline z & 55 & 55 & 71 & - & - & - & - & - & - \\
\hline $\mathrm{C}$ & 38 & 10 & 72 & - & - & - & - & - & - \\
\hline
\end{tabular}

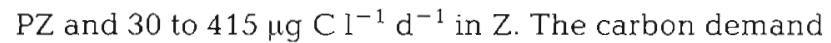
by copepods exceeded daily primary production at the end of the experiment in PZ and at the beginning of the experiment in $Z_{\text {; }}$ this pattern is similar to that observed for bacteria. Daily phytoplankton consumption by the copepods was also estimated from grazing experiments using isotopically labelled prey (Roman \& Rublee 1981). Ingestion rates ranged from 64 to $818 \mu \mathrm{g} \mathrm{C} \mathrm{l}^{-1}$

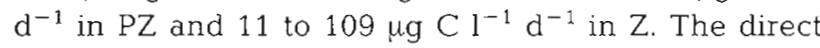
ingestion estimates follow the same pattern as ingestion estimated from gross growth efficiency and correspond to daily rations of 13 to $255 \%$ body $\mathrm{C} \mathrm{d}^{-1}$. Both types of ingestion estimates result in carbon uptakes which exceed daily primary production during certain times of the experiment. As HNAN are approximately 2 to $5 \mu \mathrm{m}$ in diameter, they are of a size that is potentially available to Acartia tonsa (Nival \& Nival 1976). Comparing the mass balance between the production and biomass of HNAN (Table 5), we see that there is greater loss of HNAN carbon in the vats with copepods $(\mathrm{PZ}>\mathrm{P}, \mathrm{Z}>\mathrm{C})$. Similarly, there often is a greater abundance of HNAN in the vats without macrograzers (Fig. 1). As copepods are unable to ingest significant quantities of bacteria, their uptake of ${ }^{3} \mathrm{H}$-thymidine labelled particles is primarily due to ingestion of HNAN that have ingested labelled bacteria (Roman 1984). Assuming that all of the label in the copepods comes from the flagellates, ingestion rates range from 11 to $34 \mu \mathrm{g}$ flagellate $\mathrm{C} \mathrm{I}^{-1} \mathrm{~d}^{-1}$ corresponding to 13 to $43 \%$ of the daily HNAN production. This ingestion of HNAN would contribute 12 to $87 \%$ of the daily carbon demand of the copepods based on their growth rate.

\section{DISCUSSION}

Although conditions in the vats were artificial, similar situations of phytoplankton blooms and copepod growth responses, bacteria increases and heterotrophic nanoflagellate responses and the general relationships between the biomass of autotrophs and heterotrophs occur in the estuarine region from which these samples were taken. The obvious advantage of using mesocosms is that they can be experimentally manipulated and the same populations of organisms can be followed over time (Grice \& Reeve 1982).

The abundance of bacteria as well as their estimated contribution to total heterotrophic carbon was highest early in the experiment but decreased over time as the populations of both HNAN and copepods increased. The initial high number of bacteria in the vats (within range found in Chesapeake Bay; Malone et al. 1986) may have resulted from a temporary release of grazing pressure due to the removal of predators when the water was filtered (1 um nominal pore size) to fill the vats. Additionally, an enhancement of dissolved organic substrates by the filtration process may have stimulated bacterial production rates. As the abundance of HNAN increased, bacterial abundance decreased. Using both published HNAN clearance rates as well as differences in the estimated production and biomass of bacteria (Table 5), we found that HNAN were capable of removing $>90 \%$ of the daily bacterial production.

The abundance of HNAN was usually lower in the vats with copepods $(P>P Z, C>Z)$. This difference 
was especially large between Vats $Z$ and $C$, where there was no initial inoculum of diatoms so that the copepods had less available phytoplankton. Our grazing experiments using thymidine-labelled prey suggest that copepods are capable of grazing HNAN. The difference between estimated HNAN production rates plus biomass and the subsequent day's HNAN biomass (Table 5) was greatest in the vats with copepods. Additionally, copepod carbon demand, estimated from their measured production rates (Table 4), exceeded daily primary production on several days in both PZ and Z. It is likely that the ingestion of HNAN contributed significantly to copepod production rates during these occasions. Direct ingestion of bacteria by copepods is not significant (Boak \& Goulder 1983, Roman 1984). However, our direct and indirect ingestion measurements suggest that the consumption of HNAN by copepods was at times an important pathway for the transfer of energy from bacteria to metazoans.

The production of bacteria (as estimated from thymidine incorporation) was higher in the vats with copepods ( $\mathrm{PZ}>\mathrm{P}, \mathrm{Z}>\mathrm{C}$ ). One factor which contributes to this higher production is a greater bacterial standing stock in the copepod vats. This phenomenon may be the result of less grazing pressure by HNAN, which had been reduced by copepod predation. If however, we normalize the production rates of bacteria by their estimated biomass (Table 3 ) we find that the highest $P / B$ ratios of the bacteria also occur in $\mathrm{PZ}$ and $\mathrm{Z}$ when copepod biomass is highest. Copepod grazing activity can result in enhanced bacterial growth rates (Eppley et al. 1981). The products of 'sloppy feeding' are both particulate and dissolved organic compounds. Additionally, 10 to $15 \%$ of the nitrogen excreted by copepods can be released as DFAN (Bidigare 1983). Although the pools of DFAN in the tanks with copepods were similar to the control vats without copepods, both regeneration rates and uptake rates of DFAN were highest in the presence of copepods. As phytoplankton have only limited ability to incorporate dissolved amino acids as compared to bacteria (Wheeler \& Kirchman 1986), we conclude that the higher uptake rates in $\mathrm{PZ}$ and $\mathrm{Z}$ were the result of bacterial incorporation of DFAN. This greater utilization of organic substrates probably resulted in both the higher production and biomass of bacteria in the tanks with copepods. Fuhrman (1987) recently reported enhanced rates of DFAN regeneration when copepods were included in seawater incubations. Field evidence for the release of DFAN was provided by Williams \& Poulet (1986) who found that during the day at a well-mixed station in the Celtic Sea, variations of DFAN with depth reflected the feeding activity of copepods. Copepod feeding and excretion may be a significant source of DFAN in the sea and provide a means for enhanced bacterial production.
The higher release rates of DFAN in the presence of copepods allows a greater proportion of bacterial nitrogen requirements to be met by organic nitrogen compounds, thus allowing more of the inorganic nitrogen for uptake by phytoplankton. Bacteria can compete successfully with phytoplankton for inorganic nitrogen (e. g. Horstmann \& Hoppe 1981, Fuhrman et al. 1985, Wheeler \& Kirchman 1986). If the available organic substrates are nitrogen-poor relative to their biomass, bacteria will supplement their nitrogen requirements by the uptake of inorganic nitrogen (Ferguson \& Sunda 1984, Hagström et al. 1984, Wheeler \& Kirchman 1986 , Caron et al. 1987). Thus bacteria may be sinks rather than sources of inorganic nitrogen. In P and PZ where the growth of Thalassiosira weissflogii reduced ammonium concentrations, there were both greater ammonium regeneration and uptake (except Day 5) in the vat with copepods. The release of DFAN by the grazers provided more nitrogen for the bacteria so that more of their nitrogen requirements were met by the organic substrate. As a consequence, a greater proportion of the ambient ammonium may have been available for phytoplankton. If the bacteria were nitrogen-sufficient as a result of the DFAN uptake, regeneration of bacterial nitrogen would also be higher in the copepod vat. Using the equation derived by Ikeda (1974), we estimate that the regeneration of ammonium by copepods was less than $10 \%$ of the observed ammonium regeneration. Although flagellates can be important as nitrogen regenerators (Goldman \& Caron 1985), in $\mathrm{PZ}$, where ammonium regeneration was enhanced, there were fewer HNAN as compared to P which had no copepods.

In an early study of the nitrogen cycle of Long Island Sound, Harris (1959) reported that approximately $50 \%$ of the daily nitrogen requirement of phytoplankton during late spring and early summer was provided by zooplankton excretion. These estimates were derived from bottle incubations $(>4 \mathrm{~h}$ ) with over 100 -fold concentrations of zooplankton (>366 $\mu \mathrm{m})$ above ambient levels. In addition, the incubations were conducted in unfiltered seawater, so that the ammonium regeneration by bacteria and protozoa could not be separated from that by zooplankton. Recent studies (reviewed by Harrison 1980, Paasche 1987) have shown that the majority of ammonium regeneration in pelagic waters is not usually by macrozooplankton, but rather by organisms $<100 \mu \mathrm{m}$, the protozoa and bacteria. However, many of these more recent regeneration studies have been based on pre-screened samples which have removed the grazers or they have used zooplankton incubated in filtered seawater, where they cannot feed and are isolated from interactions with bacteria and protozoa. Unfortunately, both of these approaches alter the natural associations of the plankton community and 
may change trophic interactions which effect nutrient regeneration. Based on their weight-specific metabolism, macrozooplankton are not likely to contribute significantly to ammonium regeneration. However, their interactions with other trophic levels, such as grazing on protozoa and 'sloppy' feeding which releases dissolved organic nitrogen compounds, can influence the nitrogen cycling by the microbial community.

In comparing the carbon pools of the plankton groups in the vats, we recognize the imprecision associated with the various conversions used to estimate carbon biomass (i. e. cell volumes to carbon for bacteria and HNAN, C/chorophyll ratios for phytoplankton). Additional variability is associated with our estimates of carbon production by the various plankton groups (i. e. thymidine-carbon conversion for bacteria, shortterm uptake of ${ }^{14} \mathrm{C}$-bicarbonate extrapolated to daily production rates for phytoplankton. HNAN production based on the consumption of bacteria and a $38 \%$ gross growth efficiency of HNAN). Considering these uncertainties, we nonetheless believe it is worthwhile to examine general relationships between the carbon partitioned in the various plankton groups in the vats to learn how trophic processes may operate in the sea, where following the same populations over time is usually not possible. In comparing the biomass of bacteria, flagellates, phytoplankton and zooplankton in the English Channel, Holligan et al. (1984) found that in frontal and mixed regions, the ratio of heterotrophic biomass to autotrophic biomass was low relative to stratified areas. For example, the carbon biomass ratio of bacteria/phytoplankton increased from 9 to $60 \%$ going from a mixed to a stratified station whereas the carbon biomass ratio of zooplankton/phytoplankton increased from 17 to $290 \%$. We found similar ratios in PZ which contained a phytoplankton bloom early in the experiment that was gradually utilized by heterotrophs over the course of our incubation. A large biomass of phytoplankton relative to heterotrophs can be a result of either a constant input of nutrients (i. e. frontal, mixed and upwelling areas) or may be a non-equilibrium condition such as a pulsed nutrient input. Conversely, an inverse biomass pyramid may be the result of either non-equilibrium conditions (early in the experiment in $\mathrm{Z}$ where only copepods were added to the vat) or be a more stable situation as a consequence of efficient utilization of algae with a high turnover rate, the production of which is driven predominantly by regenerated nitrogen. This is the situation which we observed in PZ toward the middle and end of the experiment, that Holligan et al. (1984) observed at their stratified station, and is a condition that likely persists in much of the oligotrophic central gyres of the ocean.

During the course of the vat experiment there were several days when the estimated carbon demand of bacteria and copepods exceeded daily primary production. Similarly, there were periods when estimated HNAN consumption was greater than daily bacterial production. These discrepancies are in part the result of different response times of the plankton groups, although alternate carbon sources also exist. Another way of comparing carbon flow in the vats is over the generation time of the slowest growing component (copepods). Integrating the production over the first $8 \mathrm{~d}$ of the vat experiment (some daily primary production values were estimated from production/chlorophyll ratios), we again find that the highest production of both bacteria and HNAN occurred in the vats with copepods (Table 6). Comparing the production of the plankton groups we see that bacteria production/phytoplankton production ranged from $20 \%$ (P) to $52 \%$ (PZ); HNAN production/bacteria production ranged from $38 \%$ (Z) to $50 \%$ (C); zooplankton production/ phytoplankton production was $14 \%(\mathrm{PZ})$ and $8 \%(\mathrm{Z})$; and, zooplankton production/HNAN + phytoplankton production was $12 \%(\mathrm{PZ})$ and $7 \%(\mathrm{Z})$. Given our knowledge of growth efficiencies from laboratory studies, these production relations appear reasonable and confirm that production conversion efficiencies of microbial organisms are higher than metazoans.

In rocky intertidal and coral reef communities larger organisms, which have low biomass and productivity, can be important in controlling community productivity and nutrient cycling (e.g. Payne 1966, Dayton 1971). These 'keystone' species structure the lower trophic levels by their grazing activity and thus influence the competition for nutrients and overall productivity. In lakes, both fish and zooplankton can feed selectively on lower trophic levels, resulting in 'top-down control'

Table 6. Total integrated carbon production $\left(\mu \mathrm{g} \mathrm{Cl} 1^{-1}\right)$ for Days 1 to 8 for phytoplankton, bacteria, flagellates and zooplankton in the various vats. Production ratios (\%) for bacteria/phytoplankton, flagellates/bacteria, zooplankton/phytoplankton and zooplankton/phytoplankton + flagellates over the $8 \mathrm{~d}$

\begin{tabular}{|lrrrr|} 
& \multicolumn{5}{c}{ Vat } \\
& $\mathrm{P}$ & $\mathrm{PZ}$ & $\mathrm{Z}$ & $\mathrm{C}$ \\
\hline Phytoplankton & 3711 & 2430 & 2477 & 1010 \\
Bacteria & 743 & 1272 & 1061 & 510 \\
Flagellates & 344 & 516 & 408 & 256 \\
Zooplankton & & 344 & 205 & \\
$\begin{array}{l}\text { Bacteria/phyto- } \\
\text { plankton }\end{array}$ & $20 \%$ & $52 \%$ & $42 \%$ & $50 \%$ \\
$\begin{array}{l}\text { Flagellates/bacteria } \\
\text { Zooplankton/phyto- }\end{array}$ & $46 \%$ & $41 \%$ & $38 \%$ & $50 \%$ \\
$\begin{array}{l}\text { plankton } \\
\text { Zooplankton/phyto- } \\
\text { plankton+flagellates }\end{array}$ & & $14 \%$ & $8 \%$ & \\
\cline { 1 - 4 } & & $12 \%$ & $7 \%$ & \\
\hline
\end{tabular}


of pelagic biomass and productivity (Carpenter et al. 1985, McQueen et al. 1986). Our data suggests that in marine waters, zooplankton may have a similar function at times because they can selectively graze autotrophs and bacteriovores and produce dissolved organic substrates, thus stimulating bacterial productivity and nutrient regeneration.

Acknowledgements. This research was supported by National Science Foundation Grants OCE-8406700 (Roman), OCE-8406523 (Ducklow), OCE-8406712 (Fuhrman), OCE-8407033 (Garside), OCE-8409465 (Glibert) and OCE-8406526 (Malone), as part of the MECCAS progam. We thank K. Ashton, T. Bell, J. Garside, A. Gauzens, S. Hill, S. Pike, G. Tilton, and B. Wendler for assistance in sample collection and data analysis. This is University of Maryland, Center for Environmental and Estuarine Studies contribution No. 1847 and Bigelow Laboratory Contribution No. 87022

\section{LITERATURE CITED}

Azam, F., Fenchel, T., Field, J. G., Gray, J. S., Meyer-Reil, L. A., Thingstad, F. (1983). The ecological role of watercolumn microbes in the sea. Mar. Ecol. Prog. Ser 10: $257-263$

Banse, K. (1977). Determining the carbon to chlorophyll ratio of natural phytoplankton. Mar. Biol. 41: 199-212

Bidigare, R. R. (1983). Nitrogen excretion by marine zooplankton. In: Carpenter, E. J., Capone, D. C. (eds.) Nitrogen in the marine environment. Academic Press, New York, p. $385-409$

Billen, B., Joiris, C., Winant, J., Gillain, C. (1980). Concentration and microbiological utilization of small organic molecules in the Scheldt estuary, the Belgian coastal zone of the North Sea and the English Channel. Estuar. coast. mar. Sci. 11: 279-294

Bjornsen, P. K. (1986). Bacterioplankton growth yield in continuous seawater cultures. Mar. Ecol. Prog. Ser. 30: 191-196

Boak, A. C., Goulder, R. (1983). Bacterioplankton in the diet of the calanoid copepod, Eurytemora sp. in the Humber Estuary. Mar. Biol. 73: 139-149

Borsheim, K. Y., Bratbak, G. (1987). Cell volume to cell carbon conversion factors for a bactivorous Monas sp. enriched from seawater. Mar. Ecol. Prog. Ser. 36: 171-175

Bratbak, G. (1985). Bacterial biovolume and biomass estimates. Appl. environ. Microbiol. 49: 1488-1493

Caron, D. A., Goldman, J. C., Dennet, M. R. (1987). Experimental demonstration of the role of bacteria and bactivorous protozoa in plankton nutrient cycles. Hydrobiol. (in press)

Carpenter, S. R., Kitchell, J. K., Hodson, J. R. (1985). Cascading trophic interactions and lake productivity. Bioscience 35: $634-639$

Dayton, P. K. (1971). Competition, disturbance, and community organization: the provision and subsequent utilization of space in a rocky intertidal community. Ecol. Monogr. 45: $137-159$

Ducklow, H. W., Purdie, D. A., Williams, P. J, leB, Davis, J. M. (1986). Bacterioplankton: a sink for carbon in a coastal marine plankton community. Science 232: 865-867
Ducklow, H. W., Hill, S. M. (1985). Tritiated thymidine incorporation and growth of heterotrophic bacteria in warm core rings. Limnol. Oceanogr. 30: 260-272

Eppley, R. W., Horrigan, S. G., Fuhrman, J. A., Brooks, E. R, Price, C. C., Sellner, K. (1981). Origins of dissolved organic matter in southern California coastal waters: experiments on the role of zooplankton. Mar. Ecol. Prog. Ser. 6: 149-159

Fasham, M. J. R. (1985). Flow analysis of materials in the marine euphotic zone. Can. Bull. Fish. Aquat. Sci. 213: $139-162$

Fenchel, T. (1982). Ecology of heterotrophic microflagellates. II. Bioenergetics and growth. Mar Ecol. Prog. Ser. 8: 225-231

Fenchel, T. (1984). Suspended marine bacteria as a food source. In: Fasham, M. R. J. (ed.) Flows of energy and materials in marine ecosystems. Plenum Press, New York p. 301-315

Fenchel, T., Finlay, B. J. (1983). Respiration in heterotrophic, free-living protozoa. Microb. Ecol. 9: 99-122

Ferguson, R. L., Sunda, W. G. (1984). Utilization of amino acids by planktonic marine bacteria: importance of clean technique and low substrate additions. Limnol. Oceanogr. 29: $258-274$

Findlay, S., Carlough, L., Crocker, M. T., Gill, H. K., Meyer, J. L., Smith, P. J. (1986). Bacterial growth on macrophyte leachate and fate of bacterial production. Limnol. Oceanogr. 31. 1335-1341

Frost, B. W. (1984). Utilization of phytoplankton production in the surface layer In: Global ocean flux study workshop. National Academy Press, Washington, D. C., p. 125-135

Fuhrman, J. A. (1987). Close coupling between release and uptake of dissolved free amino acids. Mar. Ecol. Prog. Ser. 37: $45-52$

Fuhrman, J. A., Horrigan, S. G., Mitchell, J. G., Capone, P. G. (1985). Bacterial and algal uptake of ammonium from seawater studied with short-lived and stable isotopes of nitrogen. EOS Trans. Am. geophys. Un. 66: 1338

Fuhrman, J. A., Azam, F. (1982). Thymidine incorporation as a measure of heterotrophic bacterioplankton production in marine surface waters: evaluation and field results. Mar. Biol. 66: 109-120

Glibert, P. M. (1982). Regional studies of daily, seasonal, and size fraction variability in ammonium remineralization. Mar. Biol. 70: 209-222

Goldman, J. C., Caron, D. A. (1985). Experimental studies on an omnivorous microflagellate: implications for grazing and nutrient regeneration in the marine microbial food chain. Deep Sea Res. 32: 899-915

Grice, G. D., Reeve, M. R. (1982). Marine mescocosms. Springer-Verlag, New York

Haas, L. W. (1982). Improved epifluorescence microscopy for observing planktonic micro-organisms. Ann. Inst. océanogr. Monaco 58: 261-266

Hagström, A., Ammerman, J. A., Henrichs, S., Azam, F. (1984). Bacterioplankton growth in seawater. 2. Organic matter utilization during steadystate growth. Mar. Ecol. Prog. Ser. 18: 41-48

Harris, E. (1959). The nitrogen cycle of Long Island Sound. Bull. Bingham, oceanogr. Coll. 17: 31-64

Harrison, W. G. (1980). Nutrient regeneration and primary production in the sea. In: Falkowski, P. (ed.) Primary productivity in the sea. Plenum Press, New York, p. 433-460

Hobbie, J. E., Daley, R. J., Jasper, S. (1977). Use of nuclepore filters for counting bacteria by fluorescence microscopy. Appl environ. Microbiol. 33: 1225-1228

Holligan, P. M., Harris, R. P., Newell, R. C., Harbour, D. S., Head, R. N., Linley, E. A. S., Lucas, M. I., Tranter, P. R. G., 
Weekley, C. M. (1984). Vertical distribution and partitioning of organic carbon in mixed, frontal and stratified waters of the English Channel. Mar. Ecol. Prog. Ser. 14: $111-127$

Horstman, V., Hoppe, U. G. (1981). Competition for the uptake of methylamine/ammonium by phytoplankton and bacteria. Kieler Meeresforsch. (Sonderh.) 5: 110-116

Ikeda, T. (1974). Nutritional ecology of marine zooplankton, Memoirs of the Faculty of Fisheries, Hokkaido University 22: $1-97$

Joint, I. R., Williams, R. (1985). Demands of the herbivore community on phytoplankton production in the Celtic Sea in August. Mar. Biol. 87: 297-306

Landry, M. R., Haas, L. W., Fagerness, V L. (1984). Dynamics of microbial plankton communities: experiments in Kaneohe Bay, Hawaii. Mar. Ecol. Prog. Ser. 16: 127-133

Malone, T C., Kemp. W. M., Ducklow, H. W., Boynton, W. R. Tuttle, J. H., Jonas, R. B. (1986) Lateral variation in the produktion and fate of phytoplankton in a partially stratified estuary. Mar. Ecol. Prog. Ser. 32: 149-160

McQueen, D. J., Post, J. R., Mills, E. L. (1986). Trophic relationships in freshwater pelagic ecosystems. Can. J. Fish. Sci. 43: 1571-1581

Mopper, K., Lindroth, P. (1982). Diel and depth variations in dissolved free amino acids and ammonium in the Baltic Sea determined by shipboard HPLC analysis. Limnol. Oceanogr. 27: 336-347

Nival, P., Nival, S. (1976). Particle retention efficiencies of an herbivorous copepod, Acartia clausi (adult and copepodite stages): effects on grazing. Limnol. Oceanogr. 21. 24-38

Paasche, E. (1987). Primary (pelagic) production in nearshore waters. In: Blackburn, T H., Sorensen, J. (eds.) Nitrogen cycling in coastal, marine environments. Wiley, London, in press

Pace, M. L., Glasser, J. E., Pomeroy, L. R. (1984). A simulation analysis of continental shelf food webs. Mar. Biol. 82 : $47-63$

Payne, R. T. (1966). Food web complexity and species diversity. Am. Nat. 10:65-75
Roman, M. R. (1984). Ingestion of detritus and microheterotrophs by pelagic marine zooplankton. Bull. mar. Sci. 35: $477-494$

Roman, M. R., Gauzens, A. L., Cowles, T. J. (1985). Temporal and spatial changes in epipelagic microzooplankton and mesozooplankton biomass in warm-core Gulf Stream Ring 82-B. Deep Sea Res. 32: 1007-1022

Roman, M. R., Rublee, P. A. (1981). A method to determine in situ zooplankton grazing rates on natural particle assemblages. Mar. Biol. 65: 303-309

Solarzano, L. (1969). Determination of ammonia in natural waters by the phenohypochlorite method. Limnol. Oceanogr. 14: 799-801

Steemann-Nielsen, E. (1952). The use of radioactive carbon $\left({ }^{14} \mathrm{C}\right)$ for measuring organic production in the sea. J. Cons. perm. int. Explor. Mer 18: 117-140

Tranter, D. J. (1976). Herbivore production. In: Cushing, D. H., Walsh, J. J. (eds.) The ecology of the seas. W. B. Saunders Co., New York, p. 186-224

Wheeler, P. A., Kirchman, D. L. (1986). Utilization of inorganic and organic nitrogen by bacteria in marine systems. Limnol. Oceanogr. 31. 998-1009

Williams, P. J. leB (1981). Incorporation of microheterotrophic processes into the classical paradigm of the plankton food web. Kieler Meeresforsch. (Sonderh.) 5:1-28

Williams, P. J. leB. (1984). Bacterial production in the marine food chain: the emperor's suit of clothes? In: Fasham, M. (ed.) Flows of energy and materials in marine ecosystems: theory and practice. Plenum Press, New York, p. 271-299

Williams, R., Poulet, S. A. (1986). Relationships between the zooplankton, phytoplankton, particulate matter and dissolved free amino acids in the Celtic Sea. Mar. Biol. 90: $279-284$

Yentsch, C. S., Menzel, D. W (1963). A method for the determination of phytoplankton chlorophyll and phaeophytin by fluorescence. Deep Sea Res. 10: 221-231

This article was presented by Dr K. R. Tenore; it was accepted for printing on October 13, 1987 